WIDER Working Paper 2020/129

\title{
Putting the financial system to work for the poor and SMEs
}

Abdul Magid Osman and Djamila Pontes Osman*

October 2020 
Abstract: The financial inclusion effort achieved positive results, with the number of Mozambicans having access to banking services increasing considerably, particularly after 201112. However, the economic and social impact was limited, considering that farm productivity has remained low and poverty levels are still high. The neoliberal doctrine in the economic sphere, its expression in the restrictive monetary policies, and the weakness of the multi-party democracy system have been institutional factors restricting economic and social development. Consequently, this study proposes some institutional reform measures to expand credit to family subsistence farmers, small and medium-sized enterprises, the population in general, and low-income families in particular. Young people could benefit from more accessible housing loans. Rural family farmers also need systemic, public support.

Key words: credit, guarantees, financial inclusion, small and medium-sized enterprises, rural family farmers

JEL classification: G18, G20, G28, Q14

Note: This is a translated version of the original paper in Portuguese, which is available here (disponível em Português).

*Independent writers, Maputo, Mozambique: amagide@gmail.com and djamila.p.osman@gmail.com

This study is published within the project on Inclusive growth in Mozambique-scaling-up research and capacity implemented in collaboration between UNU-WIDER, University of Copenhagen, University Eduardo Mondlane, and the Mozambican Ministry of Economics and Finance. The project is financed through specific programme contributions by the governments of Denmark, Finland, and Norway.

Copyright (C) UNU-WIDER 2020

Information and requests: publications@wider.unu.edu

ISSN 1798-7237 ISBN 978-92-9256-886-3

https://doi.org/10.35188/UNU-WIDER/2020/886-3

Typescript prepared by Adriana Barreiros. Translated from Portuguese by Sofia Roborg-Söndergaard.

United Nations University World Institute for Development Economics Research provides economic analysis and policy advice with the aim of promoting sustainable and equitable development. The Institute began operations in 1985 in Helsinki, Finland, as the first research and training centre of the United Nations University. Today it is a unique blend of think tank, research institute, and UN agency — providing a range of services from policy advice to governments as well as freely available original research.

The Institute is funded through income from an endowment fund with additional contributions to its work programme from Finland, Sweden, and the United Kingdom as well as earmarked contributions for specific projects from a variety of donors.

Katajanokanlaituri 6 B, 00160 Helsinki, Finland

The views expressed in this paper are those of the author(s), and do not necessarily reflect the views of the Institute or the United Nations University, nor the programme/project donors. 


\subsection{Concepts}

Throughout the text, the words institution or institutions are used to mean 'formal rules of the game that political, social and economic players should follow, individually and collectively' (Oxford Policy Management 2019: 1). The aim of these institutions is to bring order to the relationship between people and these organizations.

Ubi homo ibi societas; ubi societas, ibi jus—which means, where Man exists, there is a society. And where a society exists, there are rules. Institutions came from this need to have rules and make them something essential to the existence of Man.

On the other hand, to differentiate from 'institution' or 'institutions' which have the meaning described above, ministries, courts, assemblies, banks and companies are called 'organizations'.

However, the two concepts are linked, as the operation of these organizations assumes the existence of a set of formal, or even informal, rules for their operation. Organizations can only operate according to a standard of behaviour that is dictated by certain institutions and that makes workers almost automatically accept certain rules, hierarchies, and schedules.

The financial inclusion referred to in this text is broader than that normally used, particularly by the Bank of Mozambique. In effect, below is a selection of the relevant global goals for 2022, announced in the National Financial Inclusion Strategy (BM 2016: 40):

- 75 per cent of the total population with a point of access to financial services less than 5 $\mathrm{km}$ from their place of residence or work (GIS);

- 100 per cent of all districts with at least one point of access to formal financial services;

- 60 per cent of the total adult population with an active bank account in an electronic currency institution;

- 90 per cent of all households with at least one deposit account in a formal financial institution (INE Census 2017);

- 15 per cent of all households with at least one credit account in a formal financial institution (INE Census 2017).

In this text, we intend to highlight access to credit as a necessary condition, albeit not sufficient, for triggering a more inclusive, and therefore more sustainable, economic development process.

\subsection{Scope}

The aim of this study is to analyse the institutions that encourage or restrict financial inclusion, particularly general access to credit. To this end, and with the aim of analysing the prevailing practices and standards in the financial system, we will be analysing:

- the importance of financial inclusion, particularly credit;

- the Mozambican financial system;

- the progress made in financial inclusion in Mozambique and its impact;

- institutional barriers; 
- the proposals for measures or reforms to generalize credit for rural families and for small and medium-sized enterprises (SMEs); and

- final considerations.

\section{Importance of financial inclusion, particularly credit}

In a context of financial exclusion, access to a bank account, particularly digital platforms, is a precondition for general access to credit, which is, in our opinion, a fundamental ingredient, along with technical knowledge, for economic and social development in Mozambique. Although access to a bank account and/or a digital platform, by facilitating transactions and keeping money, represents a historic leap towards modernity, with all its implications for human behaviour, per se, unlike credit, it does not contribute directly and significantly to any substantial increase in productivity, which is, in essence, the main factor behind economic and social development. Therefore, in our analysis, we will be looking only at access to credit, assuming that this includes all the other components of financial inclusion.

Financial inclusion, including credit, must be understood as a means for achieving a more global objective, which is that of broader and more inclusive economic and social development, and not just a question of social justice, but also a means to obtain sustained economic development. Many developing countries, Mozambique in particular, cannot continue on the normal and historical route of displacement of rural populations to the cities to work in industry and the services sector. For obvious reasons, light industry cannot absorb the thousands and thousands of young people from all over the country coming every year to look for work in the formal economic sectors. And although income in the information services sector in towns and cities is higher than in rural areas, unless there is an urban population explosion, it is neither politically nor socially sustainable to turn the natural displacement of the rural population of Mozambique to towns and cities, creating areas like the favelas in Brazil or the Dharavi slum (Mumbai) or the shanty towns in Nairobi, such as Kangami, into official policy.

Therefore, it is absolutely crucial to increase productivity in farming and other rural activities, both in terms of SMEs and family farmers (rural families) to improve the living conditions of rural populations and, at the same time, create a domestic market large enough to justify the installation of a larger base of light industry and services.

In terms of family farmers, agricultural productivity in Mozambique is one of the lowest in Southern Africa and possibly in the world. Of the 3.8 million rural families (informal farmers) only 5 per cent use fertilizer and/or improved seeds. These families will not be able to escape the poverty trap resulting from extremely low productivity. They need an external jolt in the form of access to resources, including credit and modern technology. Rural families cannot run the risk of introducing new crops unknown to them, abandoning, if only partially, the previous ones, accompanied or not by new technology, because if they fail, and in the absence of savings and financial support, they are putting the physical survival of every member of the family at risk. The risk is enormous, so it comes as no surprise that country people are conservative.

Although an increase in productivity in the family sector is absolutely crucial and will very probably bring high returns on investment, because of the current situation of technological poverty, Mozambique cannot allow itself the luxury of not having a commercial SME sector in the agricultural sector, which could absorb modern techniques - and perhaps operate as centres of technical excellence-and modern production processes. The evolution from family farmer to a small commercial company is, on the other hand, an indispensable historic leap, but a difficult one. 
This is because in a world where developed countries provide massive support to their agricultural SMEs, distorting the world price system, this historic evolution will only be possible under a framework of systemic support, including financial support.

Although they have a formal relationship with the financial system, the other thousands and thousands of SMEs outside the agricultural sector constantly complain of the lack of access to credit and other financial support. As is the case in other countries, Mozambique needs a large number of modern, efficient SMEs, national or foreign, who will be the backbone of the Mozambican economy. For this to happen, there have to be appropriate institutions and access to credit.

\section{Progress in financial inclusion}

Progress in financial inclusion is made in the context of the financial system and digital platforms, so it is important to know what they consist of.

\subsection{Composition of the financial system}

According to information available on the Bank of Mozambique website, the National Strategy for Financial Inclusion for the period between 2016 and 2022, updated on 28 May 2018 at the conference on digital financial services, provides that, in addition to the regulatory institutions. the Bank of Mozambique and the Mozambique Insurance Supervision Institute (ISSM), '[...] the national financial sector consists of: (i) credit institutions and financial societies [...] (banks, microbanks and credit cooperatives) and electronic currency institutions; (ii) insurers; (iii) social security institutions and pension fund management bodies; and (iv) capital market institutions [...]' (BM 2016: 3).

According to the databases and documents mentioned above, Table 1 and Table 2 show the composition of the formal financial sector in Mozambique.

In absolute terms, the access points to financial services-i.e. the physical place where financial transactions can be carried out, particularly withdrawals and deposits, with a formal financial institution, such as bank branches and banking agents, or IMEs (electronic currency institutions), ATMs, and POSs (points of sale) —increased significantly between 2005 and 2018, as shown in Figure 1 and 2. 
Table 1: Number of financial institutions by category (2018)

Credit institutions

\begin{tabular}{lc}
\hline Banks & 18 \\
Microbanks & 11 \\
Investment societies & 2 \\
Electronic currency institutions & 3 \\
Credit cooperatives & 7 \\
\hline Financial societies & 1 \\
\hline Group purchasing organizations & 2 \\
Credit card issuing or managing companies & 13 \\
Bureaux de change & 12 \\
\hline Microfinance operators & 790 \\
\hline Savings and loan organizations & 22 \\
Microcredit operators & 13 \\
\hline Other financial institutions &
\end{tabular}

Source: authors' elaboration using the BM database (2019: 25).

Table 2: Number of agencies, agents, delegations, and branches per category (2018)

\begin{tabular}{lc}
\hline Credit institutions & \\
\hline Banks & 674 \\
Microbanks & 44 \\
Investment societies & 2 \\
Electronic currency institutions & 43,103 \\
Credit cooperatives & 7 \\
\hline Financial societies & 2 \\
\hline Group purchasing organizations & 2 \\
Credit card issuing or managing companies & 21 \\
Bureaux de change & 12 \\
\hline Microfinance operators & 790 \\
\hline Savings and loan organizations & 138 \\
Microcredit operators & 612 \\
\hline Other financial institutions & \\
\hline Insurance institutions & \\
\hline Stockbrokers & \\
\hline
\end{tabular}

Source: authors' elaboration using the BM database (2019: 25). 
Figure 1: Number of bank branches (in blue) and IME agents per 10,000 km²

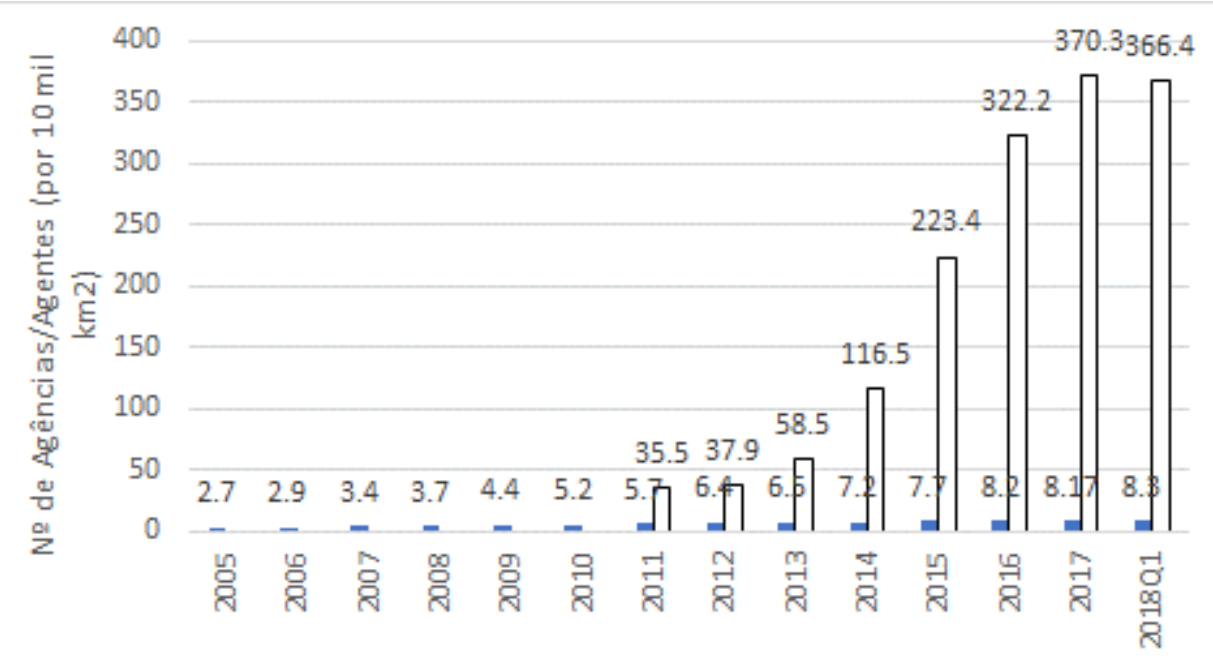

- Agências bancárias (por $10 \mathrm{mil} \mathrm{km2) \quad \square Agentes} \mathrm{de} \mathrm{IME} \mathrm{(por} 10 \mathrm{mil} \mathrm{km2)}$

Note: IME = electronic currency institutions.

Source: authors' elaboration using the Fernandes database (2018: 11).

Figure 2: Number of ATMs and POSs per $10,000 \mathrm{~km}^{2}$

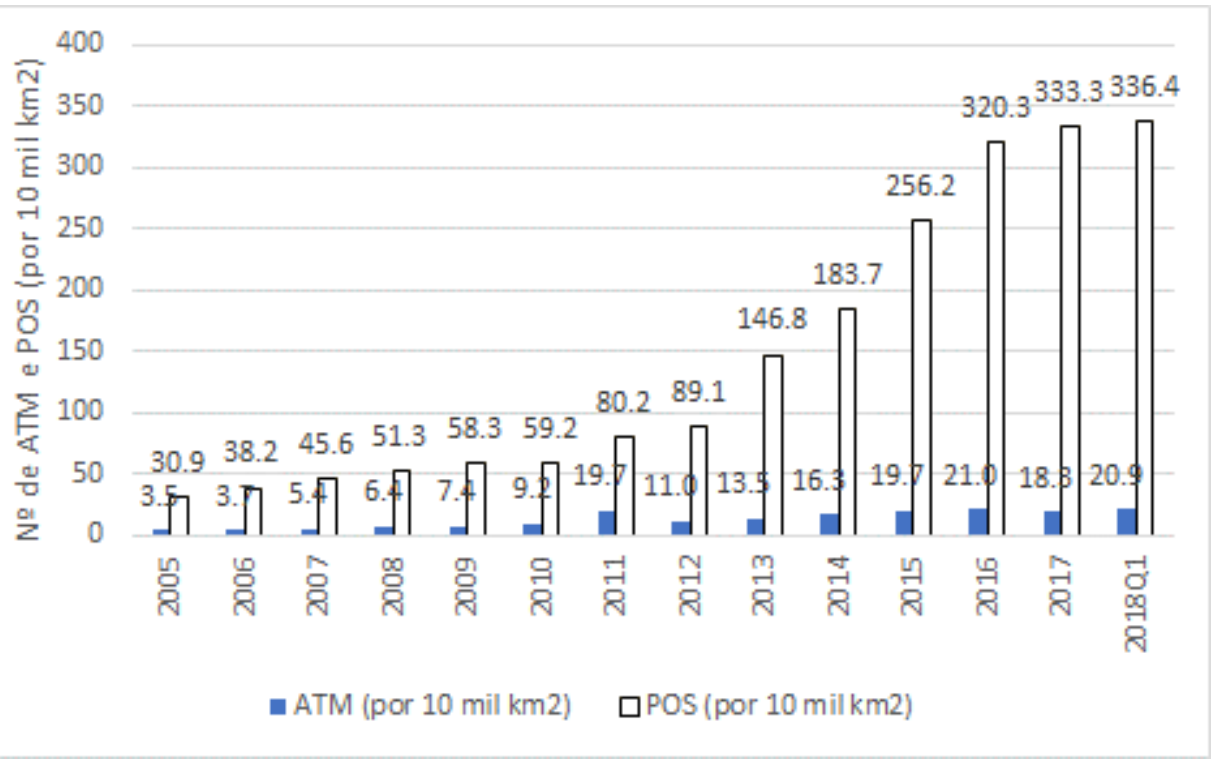

Note: ATM = cash machine; POS = point of sale.

Source: authors' elaboration using the Fernandes database (2018: 11).

On the Bank of Mozambique website, we were also able to analyse the figures for electronic banking, through data from September 2019 (BM 2020). According to these data, in Mozambique, there are 1,774 ATMs, 35,441 POSs, 5,059,686 bank accounts, 2,900,830 bank cards, 2,706,986 subscribers to mobile banking and 493,492 subscribers to internet banking.

However, the absolute figures presented above need to be looked at in conjunction with the demographic and geographical information available in order to draw some conclusions as to financial inclusion. We have tried to do this throughout the text, and we can conclude that it is really very low, as we will comment on below. 
As we have seen above, the access points increased significantly between 2005 and 2019. However, in geographical terms, a very high percentage of these access points are concentrated in urban areas, particularly in Maputo City, despite 66.6 per cent of the total population living in rural areas (INE 2019b: 38).

\subsection{Financial inclusion, support, and progress}

The importance of the financial system to economic and social development has been recognized by several donor organizations, particularly the United Kingdom government agency for international development-Department For International Development (DFID). The DFID, in partnership with other international organizations, has developed a set of initiatives to promote access to financial services for people who do not have bank accounts or who do not use mobile operator financial platforms. These initiatives are now called financial inclusion initiatives.

Of these different initiatives, of note is Financial Sector Deepening Moçambique (FSDMoç). This entity was founded and co-funded by UK Aid with other international partners. It works towards the development of the financial sector and especially the expansion of financial inclusion. FSDMoç has promoted some studies related to this topic, including market studies to analyse the constraints and opportunities and to make proposals for measures to promote financial inclusion.

Below, based on the studies published, we will briefly describe the factors that have contributed most to financial inclusion.

\section{Positive factors}

The digitalization of banking services-debit and credit cards, ATMs and POSs, e-banking, and other applications since created by the banking system - has played a decisive role in the extension of financial services to an increasingly higher percentage of the population.

The development of financial platforms by telecommunications companies, particularly M-Pesa by Vodacom and Mkesh by Mcel, has made a significant contribution to the extension of access to financial services by economic agents. Although these platforms do not have a banking licence, they carry out specific functions in the banking sector, such as deposits, withdrawals, transfers, payments of good and services, etc., which has the advantage of relieving banks of these duties, as the M-Pesa or Mkesh agent will do these duties when necessary at a minimum cost. The increasing coverage of the country by telecommunications networks and the widespread use of mobile phones is also a decisive factor.

The Bank of Mozambique has also contributed greatly to the expansion of physical access points, with the approval of several notices, namely: (i) Notice No. 4/GBM/2012, of 26 December, on the extension of financial services to rural areas; (ii) Notice No. 1/GBM/2015, of 22 April, on the rules and criteria for opening and closing bank branches; and (iii) Notice No. 3/GBM/2015, of 4 May, which regulates access to and engagement in the activities of banking agents. Based on the system established, it is now possible for banks and microbanks to extend their activities, or a relevant part of these, to rural areas by contracting bank agents. Unfortunately, we were unable to find any statistics or data on the impact of this system on the expansion of banking activities, but it is to be expected that this measure will have a very positive impact on bank representativeness nationwide.

Finally, the Ministry of Land, the Environment and Rural Development (MITADER) is developing the 'One District, One Bank' programme under the scope of the National Programme for Sustainable Development (MITADER 2016). The aim of this programme is to accelerate the 
process of access to banking services in rural areas through the granting of loans and other facilities to financial institutions so they can open branches in 72 districts. The programme has been underway since 2016 and is being joined by large local commercial banks, particularly from the time the programme began including a contribution in terms of donations to cover operating costs for a number of years, given that the majority of the branches in the districts are not profitable.

\section{Results achieved}

Financial inclusion in Mozambique, although lower than most of its peers in the Southern African Development Community (SADC) (Mauritius has the highest inclusion rate) has been very dynamic in recent years, as can be seen from the data shown below:

1. In 2009, only 1.35 million people in Mozambique had bank accounts. In 2014, this figure had more than doubled to 2.8 million people (COWI 2015: 7). As a result, the percentage of the population without access to banking services fell from 78 per cent (in 2009) to 60 per cent (in 2014) (Vletter et al. 2015: 30). In 2017, the total number of bank accountsin national and foreign currency — was 5,093,737 (BM 2019: 32). Unfortunately, this figure cannot tell us how many people have bank accounts (as one person may have more than one bank account and companies are also included in this figure), but if we compare it to the number of bank accounts in 2014 - 3,577,102, according to the statistics from the Bank of Mozambique-we can get an idea of the changes occurring in people's access to banking services during this period (Vletter et al. 2015: 12).

2. The changes occurring in the use of mobile phones were even more spectacular in recent years, as around half of the people in Mozambique now use mobile phones (14 million subscribers in 2018) (INE 2019a: 81). At the moment, only 3.3 per cent of subscribers $(470,000)$ use mobile banking services; however, the growth potential is huge and the impact this growth could have on the increase in financial inclusion is enormous (COWI 2015: 10). People who have a phone in their pocket also have a virtual bank in their pocket.

The existence of this platform allows for the development of other businesses, such as the case of credit sales of solar home systems using a pay as you go method. This business, more than just selling solar equipment, establishes financial platforms that permit credit sales, i.e. payment in instalments via M-Pesa. This system, which has proved its worth in several countries, could be generalized for other fundamental operations for a generalized increase in productivity in the countryside, including operations such as: water pumps, irrigation systems for communities, sewing machines, cold rooms, etc., associated with solar energy and chips that allow the systems to be shut off in the event of default.

3. The combined effect of the Notices from the Bank of Mozambique mentioned above and the 'One District, One Bank' programme is remarkable, as 89 districts out of a total of 154 in Mozambique already had a working bank branch in 2016. This figure had increased by 10.8 percentage points in 2018 (BM 2019: 62; Fernandes 2018: 12).

\subsection{The economic and social impact of financial inclusion}

The increase in the number of people with access to banking services was remarkable, as a result of the different programmes implemented in recent years and referred to above. However, this success was not reflected in a reduction in poverty in the countryside as, according to a recent communication from the Ministry of the Economy and Finance, the absolute poverty index went from 46 to 60 per cent in the period between 2015 and 2019. One of the explanations for this increase is the economic crisis of 2015-16, which resulted in an increase in market basket prices 
of 55 to 70 per cent in the 2014-16 period and, as there was no salary correction in the same proportion, the purchasing power of the urban population was significantly eroded. This explanation, although relevant to the urban population, does not explain the increase in poverty recorded in rural areas, particularly among families where no member earns a formal salary. This is because these families, particularly those who work with export products did not suffer the same erosion of purchase power, as the sale prices of their products benefited from the steep devaluation of the metical. Therefore, the 2015-16 crisis does not explain the increase in rural poverty.

There are not sufficient data to definitively conclude that there is not a strong correlation between the increase in financial inclusion and the increase in productivity in rural areas as a result of the reduction of poverty. More specialized surveys will have to be undertaken to try to establish a correlation between people who have recently been given access to banking services and the increase in productivity. But it is known that SMEs, and particularly rural family farmers continue not to have access to credit. This is because one of the reports consulted makes it clear that access to credit is still extremely low and only 304,000 ( 8 per cent) of the 3.8 million rural family farmers have access to credit and, of these, only 114,000 have access to formal credit. The existence of a bank branch in a district, while important due to the other financial services it can provide, does not necessarily mean greater readiness of the bank to grant credit to SMEs, much less to family farmers, because of the inherent credit risks and high administrative costs, with the exception of agricultural trading companies, including outgrowers and general retailers.

Knowing that the majority of family farmers do not have monetary savings (what they have is temporary liquidity when they sell their products) or food stocks-and, therefore, in the absence of credit or other support, they do not make the necessary investments in their farms with a view to increasing production-nor do they have working capital for buying improved seeds and fertilizer, there is no way for them to increase productivity. The only ones to escape from this depressing scenario are the ones who are part of an outgrowers system, for example tobacco, as they have access to credit and technology and even so, have an annual monetary income of only MZN50,000 (less than USD1,000). The other producers, even those included in outgrowers systems, other than tobacco, probably have an annual income much lower than that earned by families working in tobacco.

Under these circumstances, the impact of financial inclusion without access to credit is quite limited and not even the argument that it helps encourage savings that would otherwise just be hoarded is not very relevant, because the additional savings collected are insignificant and have only the symbolic value of highlighting the importance of and the need for savings. The following statistics obtained through sampling (from two banks) show how savings are distributed by depositor and by region.

Nationwide:

- Less than 3 per cent of depositors hold 97 per cent of deposits;

- Less than 1 per cent of depositors hold 92 per cent of deposits.

The concentration is even higher in Maputo City:

- Less than 3 per cent of depositors hold 99 per cent of deposits;

- Less than 1 per cent of depositors hold 96 per cent of deposits.

There is less concentration in the provinces than in Maputo City:

- Less than 3 per cent of depositors hold 89 per cent of deposits; 
- Less than 1 per cent of depositors hold 75 per cent of deposits.

The province with the lowest concentration is Niassa Province:

- Less than 3 per cent of depositors hold 8 per cent of deposits;

- Less than 1 per cent of depositors hold 65 per cent of deposits.

The 3 per cent of depositors that hold 97 per cent of deposits nationwide are almost all based in cities or are companies of a certain size. Although it was not possible to gather more specialized data, it can be assumed that the sum of the deposits belonging to rural farmers is not even 0.5 per cent of the total of deposits and the annual increases in terms of values are probably insignificant.

Small companies ${ }^{1}$ based in towns and cities also complain of the lack of access to credit or programmes for access to knowledge and technology, although they do have access to a multitude of bank services. However, there are specific programmes, some funded by the international community and others using banks' own resources, that have no impact because they are small in size and, for this and other reasons we will explain further ahead, they do not cover the majority of the universe of small companies.

In this context, and assuming that financial inclusion is a means to a nobler end, which is the improvement of the material living conditions of the people through an increase in productivity, its economic and social impact will be small, especially if it is not accompanied by significant increases in access to credit, integrated into a wider programme of access to knowledge and technology.

However, it is important to point out that the financial inclusion of the population creates an enormous opportunity for access to credit which would otherwise be more difficult and, above all, inefficient. The platforms for the credit sales of solar kits are a good example of how to make credit available efficiently and at less risk.

\section{$4 \quad$ Institutional framework and constraints}

\subsection{Macro-institutions}

In our analysis of the macro-institutions referred to in the terms of reference, we will deal only with those that are directly relevant to the topic under discussion (Oxford Policy Management 2019: 2). In this context, the relevant institutions are those associated with Voice, participation, and political accountability. In relation to this institution, in the early years of national independence, under a single-party regime, direct democracy was followed through people's meetings at all levels, where any member of the population had the opportunity to state their concerns, their needs, criticize and report less than favourable practices of leaders and hear their justifications and arguments explaining what it had been possible to do, as well as what had not been done. The state regime had legitimacy. At central level, the state was very independent from external players and major strategic decisions - such as nationalization and applying sanctions to Ian Smith's regime (which gave rise to the war of destabilization) - were made without external

\footnotetext{
${ }^{1}$ The official version of a small company is one that employs four to ten workers and whose turnover does not exceed MZN1.2 million (around USD17,000), while a medium-sized company employs between 11 and 100 workers and has a turnover of between MZN15 and 80 million.
} 
pressure. In this context, the institutions associated with State capacity and independence from private interests, as well as the associated Sovereignty and independence, were clearly present. In addition, the regime was extremely concerned about correcting the regional imbalances inherited from the colonial period and the needs of the people were in fact a priority when designing economic policies and programmes. The cooperation proposals with third parties reflected these concerns. At that time, the institutions associated with the Rule of law and judicial independence were absent.

Obviously, with the destabilization that was experienced at that time, violence, but not violence imposed by the state, was generalized.

Over time, and with the inversion of national priorities-defence and security became the priorities - these practices were abandoned, including community justice practices. Destabilization and other issues directly and indirectly associated with this put an end to the popular, nationalist regime. There remains then the legitimate question if it would have been possible to maintain this regime if there had been no destabilization-possibly not, but the disaster would not have come so quickly or been so complete.

The introduction of multi-party, representative democracy has (still?) not been able to correct all the institutional gaps created in the meantime. A description of the current status of these macroinstitutions, while fascinating, is not the aim of this paper, but in the proposals for measures we present, we are aware of these limitations and we are particularly concerned about the institutions associated with Voice, participation, and political accountability, as the most disadvantaged cannot find suitable channels of communication to express their concerns. The electoral process, while crucial to the political process, does not give an adequate response, as its elected representatives do not feel the need for dialogue with the voters. Under these circumstances, the measures proposed will have to be motivated from the top, although an effort for the involvement of other players will have to be made in their implementation. At this stage, the base has no way of proposing sophisticated measures and ensuring that they are accepted-for example, at the Annual Private Sector Conference, dozens of recommendations are approved, many are repeated every year and rarely implemented, because many of them are unrealistic and a few others are not included in the government programme.

There are important constraints to making the measures proposed feasible in the institutions associated with Sovereignty and independence and State capacity and independence from private interests, as the serious economic and financial situation in the country has further worsened the incapacities of the state. With the hidden debt crisis, donors cut their support to the state budget, which led to a generalized cut in public spending, even in vital sectors such as health and education. As if that were not enough, even the responsibility for the implementation of sector programmes is diverted away from the state. This attitude, justified by the discrediting of the state, has the effect of worsening institutional gaps... and objectively confirms the conspiracy theories that there is a plot to turn Mozambique into a failed state.

In an atmosphere such as this, the neoliberal doctrine of the economic sphere has become deeply rooted in governing spheres, as it is totally appropriate to use the market or refer to the market forces for the solution to serious social problems in the country. The monetary policy followed by the Bank of Mozambique is the most visible expression of the dominance of neoliberal doctrine.

\subsection{Monetary policy}

The monetary policy followed by the Bank of Mozambique is an expressive result of this neoliberal process. In effect: 
1. Even before the economic crisis in 2015-16 (crisis caused by the fall in external support as a result of the revelation of illegally contracted debts), the government was 'forbidden' from engaging in support policies for national industry, subsidising interest rates, promoting housing policies and mainly, by opting for a strong metical, stimulating imports to the detriment of exports. During this process, country people were prejudiced against because the prices of their products did not increase because of the strong metical, notwithstanding the high domestic inflation rates.

2. After this crisis, the monetary policy was basically maintained, with the exception of the strong metical, with controlling inflation having gained more dominance, which led to increases in interest rates, mandatory reserves, etc. Now, as in the past, it is unthinkable to have subsidized interest rates, for example for buying houses, notwithstanding the extreme lack of housing, especially for young people, even if the subsidy comes from third parties. Sometimes, programmes that are intended to make donor community funds available through commercial banks, with interest rates slightly lower than market rates for specific sectors (solar energy), encounter resistance from the Bank of Mozambique.

3. These policies, under the pretext of controlling the inflation rate, are suffocating the emerging private sector and putting national businesspeople at a disadvantage when competing with foreigners, as they have to incur debt in national currency, at prohibitive interest rates, even when they are entitled to be paid in foreign currencies for the services provided, while foreign companies can incur debt in USD or another international currency at extremely low interest rates.

4. The need to control possible money laundering leads to absurd requirements for opening bank accounts: an income statement, tax number and, in particular, proof of residence, in addition to the legitimate requirement of a valid identification document. This posture sometimes leads banks to question the origin of a deposit of MZN20,000 (less than USD300).

5. Real interest rates, possibly some of the highest in the world, stand in the way of the development of SMEs in Mozambique and essentially result from the policies of the Bank of Mozambique, although financial margins (the difference between the weighted average rate of deposits and the average lending rate) are very high (between 6 and 8 per cent). But the decisive contribution is a result of other measures by the Bank of Mozambique, such as mandatory reserve rates, standing lending facilities, etc. Even in a situation of economic recession due to the pandemic, with prices falling, the prime rate is still 16 per cent and note that, on top of this prime rate, there is a spread that is sometimes significant for SMEs.

There is no doubt that during the 2015-16 crisis there was a need for dramatic measures to contain the devaluation of the metical and, at the same time, drain liquidity to circumvent inflation, but, four years later, maintaining the same policy reveals a total lack of consideration for the production sector.

\subsection{Financial system and granting loans}

The Mozambican financial system is relatively sound, especially when it comes to the four main banks, which represent around 77 per cent of bank assets, although three financial institutionsBCM and Banco Austral and, more recently, Moza Banco-have requested state intervention (a bailout). These banks, although they have almost all joined the 'One District, One Bank' 
programme, grant few loans to SMEs, particularly small companies, and practically none to family farmers, for a variety of reasons, the following ones being worth mentioning:

- they do not need to, because the paradigm in force does not 'oblige' them to, as they are already very profitable, as can be seen from the data in Table 3;

- banks rarely leave their comfort zones of their own free will because, even in times of crisis, their profits continue to increase. From 2017 to 2018, bank profits expressed in MZN increased 28 per cent and, from 2018 to 2019, they increased again (and as exchange rates were stable, the growth was real). In addition, they can put their surplus liquidity into government bonds and treasury bills, which assure good remuneration and do not consume capital;

- conventionally, working with (granting loans to) rural families and even small companies is complex and difficult, as they have no guarantees to give, and even when there are real assets, in the event of default, these are very difficult to execute because the judicial system is extremely slow or because society does not easily accept foreclosures on housing loans, especially when this is the only asset the family has.

Table 3: Return on average equity and Solvency ratio (2018)

\begin{tabular}{lcc}
\hline Banks & ROAE (\%) & Solvency ratio (\%) \\
\hline BIM Millennium & 22.3 & 39.0 \\
Standard Bank & 26.2 & 19.4 \\
BCl & 25.2 & 17.0 \\
Barclays & 22.7 & 23.1 \\
\hline
\end{tabular}

Note: ROAE = return on average equity.

Source: authors' elaboration using the KPMG and AMB database (2019: 35-36).

Microcredit institutions, although relatively numerous, are limited in terms of values and do not have much growth potential. Examples such as Grameen Bank cannot be repeated, as this bank developed thanks to donations from donors (hundreds of millions in USD) and now the donor community does not consider support to microcredit institutions to be a priority. They have to mobilize funds from the monetary market at high costs, so they are also obliged to charge extremely high interest rates (over 50 per cent) on their loans to cover the cost of the money and the high administrative costs. Because of the difficulties mentioned, the larger microcredit institutions are gradually abandoning the microcredit business to devote themselves to banking with medium-sized companies.

The new digital platforms, such as that used by the companies involved in the sale of solar kits and other products, if developed and adopted by commercial banks, are the best alternative to microcredit institutions.

\subsection{Guarantees and commitment}

Commitment means how much the economic agent is willing to give to a certain project, which translates into invested capital, the few assets given as a guarantee and the willingness to give up a well-paying job to take the leadership of a project whose success is still not assured.

In the loan granting process, or even in the case of a donation, or when setting up a partnership, this kind of commitment is absolutely vital because, without it, the resources provided will be wasted, opportunistic vices will be created and, particularly, the opportunity to support another economic agent with more commitment will be lost. 
In the case of family farmers and the small company segment of the SME universe, it is impossible to check the commitment or the potential of the economic agent on a case-by-case basis, even when information is gathered from local administrative authorities. Therefore, the simplest way of measuring commitment or the degree of commitment is through a real guarantee or something that has material value for the economic agent in question. In the particular case of families, their most valuable asset (very often their only one) is their cultivated land and some assets built or planted there. Title to rural land, if there is any, is by the right to use and benefit from the land (DUAT), which cannot be used to make transactions and therefore is of no value as a guarantee. In addition, in the absence of a tradition of simple, transparent and safe transfer of titles, even if the legal obstacles to using them for transactions were to be removed, it would be necessary to create an administrative mechanism capable of keeping records of allocations and transfers with security and confidence for all the parties and, in particular, for financial organizations.

The inability to give guarantees, both on the part of family farmers and a significant number of SMEs, is a major constraint to the generalization of credit, in addition to those referred to previously.

\subsection{Constraints of economic agents themselves}

The economic agents to whom it is intended to extend financial inclusion, including access to credit, themselves have many restrictions and constraints, which have to be identified and analysed, otherwise the measures proposed may prove inadequate. To analyse these restrictions, we will consider only the social categories most subject to financial exclusion, which are:

- family farmers;

- SMEs; and

- a part of the urban population.

\section{Family farmer}

As clarified in the report, 'Promoting the financial inclusion of Small Family Farmers in Mozambique', the vast majority of these family farmers 'engage mainly in farming irrigated by rainwater and use traditional crop varieties, low capacity fertilizer and a minimum of pesticides. Farming is generally done without mechanization and productivity is normally low' (FSDMoç 2017: 7). This description applies to the overwhelming majority of family farmers who engage in subsistence farming and whose number is estimated to be around 3.8 million (implying a population of around 19 million people).

Any programme for financial inclusion, including credit, cannot ignore this universe of two thirds of the Mozambican population. For a variety of reasons, which are not the subject of this analysis, these farmers did not in the past, and still do not, receive any significant support for increasing productivity. But the state has made considerable efforts with regard to education and public health, as well as in other infrastructures, such as roads. And it was only recently that the state, with the support of the World Bank, began a programme called 'Sustenta', aimed at providing access to modern technology and to credit.

We believe that multifaceted support to this sector is not a question of social justice, but rather economic rationality, as the investments will bring an enormous return due to the technological underdevelopment of these economic agents. This social category encompasses very different realities, particularly the following: 
- farmers who informally employ day or ganho-ganho labourers; ${ }^{2}$

- farmers who have access to credit from the formal or informal sector;

- farmers who are part of outgrower programmes and/or farmers associations (ASCAS); or

- farmers who have accounts on digital platforms, i.e. carrying out financial operations on a digital platform.

Unfortunately, the majority of family farmers do not belong to any of these groups, but those who belong to one of more of these groups are an important strategic asset and can act as a nursery for future SMEs, because:

- they take a risk when they hire labourers, against a future profit;

- therefore, they may, in some cases, be better disposed towards experimenting new crops;

- the risk may be extended to the acquisition of improved seeds and fertilizer;

- part of their production is sent to the market and so they already have established commercial relations; and

- they already use more appropriate techniques for storage and conservation, or they are interested in this.

To sum up, they are agents who are introducing capitalist production relationships in the fields, which represents a historic leap. And that is why they should be the subject of an intervention programme especially designed for this purpose.

\section{Small and medium-sized enterprises (SMEs)}

SMEs can also encompass very different realities, as they can include both companies that have regular relationships with commercial banks, including access to credit, and thousands and thousands of small companies which, despite having formal relationships with banks, do not have access to credit for a variety of reasons. Our aim is to deal only with small companies and particularly those that have difficulty in meeting the requirements for obtaining a loan from commercial banks.

Since the 2015-16 crisis, these banks have made an additional effort, with support from credit lines made available by the international community, to define specific support programmes for these small companies. This additional effort is the result of the incentive provided by the donor community with the credit lines, but also the surplus liquidity in the banking sector, as mediumsized and large companies do not absorb the credit capabilities of the national banking sector. But the values available to small companies are not significant and they still suffer from the problem of guarantees. Therefore, these banks will continue to place their surplus liquidity in treasury bills issued by the central bank, even if the interest rates are not very competitive and notwithstanding foreign shareholders in Mozambican banks showing increasing concern about excessive exposure to the state.

As we have said, and with the exception of the Sustenta Programme already mentioned, these support programmes are small and therefore do not have the desired impact, as needs are enormous and the existing programmes or those being prepared will only reach a very small part of this universe of small companies.

\footnotetext{
${ }^{2}$ Service provided informally or for a short time in exchange for money or food. It is the equivalent of casual labour.
} 
As we already mentioned, there are also many limitations for small companies, both in terms of guarantees and in terms of technical capacity (for presenting simple business plans). If these issues are not resolved, an important part will continue not to be eligible for credit. While an increase in technical support can and should be resolved through direct administrative support, the eligibility of companies cannot be left completely in the hands of the market.

The limitation factor common to different types of small companies is their inability to provide guarantees to meet the sometimes absurd demands of commercial banks.

Tens of thousands of small companies - from women involved in trade to mukheristas and small construction companies, repair garages, art studios, etc., which reproduce in Mozambique the historical process of transforming labourers and specialized workers into small businesspeople who will eventually grow and become medium-sized and large companies-need support, particularly in sharing the risk for obtaining bank loans at reasonable interest rates and not those charged by microcredit institutions.

\section{Population in general}

Finally, there is a vaster group of people who have still not been covered by the 'financial inclusion' process, not even in its most restricted and basic form, just having a bank account, or having an account on the M-Pesa digital platform or other similar ones, despite having a mobile phone (the latest statistics show that there are at least 15 million mobile phones in the country.) Very few people use platforms like M-Pesa or Mkesh. For these people, the hope is that their economic and social progress will come as a knock-on effect.

In fact, if the support programme for rural families and SMEs is successful, thousands of jobs will be created. In the process, many of these workers will create small companies and bring new technology to their households, making them more productive.

Although the indirect effect may be enormous in terms of jobs and more business dynamics, there are also specific problems that will also require special measures, such as housing in towns and cities, especially for young people who do not have access to credit for the reasons already mentioned-absence of guarantees, very high interest rates and more, typical of the construction sector.

\section{$5 \quad$ Measures to be proposed}

Before we present the measures aimed at increasing access to credit as a fundamental element of financial inclusion, it is important to insert a word of caution. This is because the measures proposed assume a radical alteration in the prevailing institutions and, generally speaking, in the governance of the country, in such a way that:

- the rural world is no longer neglected as it has been in recent decades;

- the scarce national and foreign resources are used rationally, giving priority to more productive investments with a greater economic and social impact;

- new, more realistic sector policies are implemented, for example, making technical education an important component of the general education system, with the existing infrastructures being used for this purpose. Construction and construction industry policies are adopted to reduce construction costs, etc. 
Measures that are only financial in nature will certainly not be sufficient for the radical transformation intended. Other institutional changes are necessary, and the international and national crisis is a unique opportunity for this change The military situation in Cabo Delgado, although essentially as a result of jihadist terrorism, has brought to light the dramatic living conditions of rural populations, particularly young people. The international crisis in the oil and gas sector and the postponement of the investment decision by the consortium led by Exxon and the possibility of crude oil prices remaining low may show that, after all, the fabulous public revenue of billions and billions of USD will not be so fabulous after all, and, in particular, this will only come in the 2030s. Therefore, it will be necessary to define new, more realistic policies for the coming years and ensure more wide-reaching and sustainable economic development. This and other dramatic events and the deep economic recession can and should create a national environment for profound reflection and create subjective conditions favourable to a radical change of action by the government.

The measures proposed below, although of limited reach, are, even so, too radical in the current institutional context. For example, it is unlikely that the Bank of Mozambique would abandon its current monetary policies of its own free will. But we hope that the discussion on the measures proposed and others that may be submitted in the meantime will force the revision not only of the monetary policy, but also of other policies. A microscopic virus has brought humanity to its knees; organizations and countries are implementing policies believed unthinkable and, in this context, Mozambique has to dare to think differently and better.

\subsection{Under the scope of monetary and fiscal policies}

The support measures for the rural world and for SMEs do not stand much of a chance of being implemented given the current institutional monetary framework. A new balance will need to be found between the spheres of action of fiscal and monetary policies. This is because although the mission of the Bank of Mozambique to protect the metical cannot be underestimated, at the risk of Mozambique falling into a situation of hyperinflation like Zimbabwe, it is necessary to somehow escape from the straitjacket created by the Bank of Mozambique's monetary policy. An alternative would be to move some initiatives from the control of the Bank of Mozambique to the control of the government, under the scope of the fiscal policy.

For example, the measures proposed to support family farmers could be carried out through an agriculture bank, but a bank only in name, as it would be a development financial institution that would not accept deposits from individual or institutional customers so that its activities would not constitute a systemic risk for the financial system. The resources for its credit activities would come from the state budget and/or the donor community. The effectiveness and efficiency of this institution will depend greatly on the functions allocated to it. It should have a very clear mission and focus mainly on financial support for family farmers and SMEs exclusively in the agricultural sector. To avoid dispersal and, mainly, the waste of resources, the credit amount to be assigned per borrower should be limited and funding of infrastructures excluded.

This institution would not be dependent on the ratios commercial banks are subject to, such as solvency ratios and others. However, it would be subject to banking supervision to check certain parameters, yet to be set.

In the same way, management of the credit lines developed with funds donated or loaned by the donor community, although distributed through commercial banks, should not be under the responsibility of the Bank of Mozambique, but rather the Ministry of the Economy and Finance, which would have the privilege of defining the interest rates and the risks it intends to share with the commercial banks. In this context, relations with the World Bank and other development 
financial institutions would no longer be under the purview of the Bank of Mozambique, moving to the Ministry of the Economy and Finance, which should create technical capacities so that the application of resources, particularly external resources, is carried out in accordance with the national priorities defined above and no longer a result of conversations lacking in transparency between local and central bodies in the country and the companies from the donor countries, with tacit support from their governments.

The Bank of Mozambique, under the scope of the major efforts it has undertaken for financial inclusion, could adopt the notion of a basic account. All that would be needed to open one of these accounts would be the presentation of an identification document (ID card or even voter's card), establishing that transactions in these accounts cannot exceed a certain amount, for example MZN20,000.

\subsection{Support measures for SMEs}

\section{Guarantee Fund}

There are many initiatives and many credit lines for financial support for SMEs, with interest rates (15 per cent) lower than commercial rates. These credit lines are placed through commercial banks which, following normal commercial practices, require real guarantees and, sometimes, with a market value higher than the loan amount. A large number of the SMEs cannot present these guarantees, even if the project or business to be developed has a lot of merit and there is major commitment from the economic agent. For example, for a loan of USD10,000, the bank asks for an asset valued at between USD120,000 and USD130,000 as collateral, while the businessperson only has a home valued at USD5,000 where they live with their family. Here, the commitment of the businessperson is total, as they will be putting at risk something that is fundamental to their and their family's existence, but the bank, according to normal standards, cannot agree to this operation. This operation will only be possible if a third entity covers the difference or gives an additional guarantee.

To bridge this important gap in business development, we propose the creation of a National Guarantee Fund, similar to common practices in several countries in the world, to promote exports or even for the development of projects that would not be feasible without these guarantees. Aware of this need for guarantees, some donor countries have created guarantee programmes that can be used by companies in developing countries. Unfortunately, these facilities are not within the reach of the majority of Mozambican SMEs and they also have a very high minimum value for the target companies.

There are also national guarantee programmes, set up with the support of donors or not. However, the proposal presented here differs from the initiatives in progress for the following reasons:

- it will be a fund exclusively devoted to granting guarantees, thus avoiding the dishonesty existing in organizations which generate both guarantees and loans. With the result that these organizations also operate as a holding company for investments made in other companies;

- it will be an independent, for-profit organization and, if possible, with private interests. Its governing bodies will be indicated by the founders, with minority participation by the state in the board of directors, more for the purpose of supervision than for management;

- it will be an organization with transparent management and supervised by the Bank of Mozambique;

- it will have its accounts audited by companies of international repute. 
The additional guarantee given by the Guarantee Fund should be complementary to the effort made by the actual businessperson, who will continue to put their own assets at risk. This means that the guarantee provided by the borrower will be the one executed first. The Guarantee Fund is a way of subsidising loans to small companies by covering a part of the bank guarantee.

\section{National effort for the development of SMEs}

The effort made by bilateral and multilateral donors in providing special credit lines must be completed by national commercial banks and, for this purpose, it is necessary that the IMF and therefore the Bank of Mozambique agree to implement a radical measure. Although it is extremely simple, it will have a major impact.

We propose that part of the amounts loaned to the SMEs, under conditions to be defined, be accepted by the Bank of Mozambique for the constitution of Mandatory Reserves.

Thus, according to this method:

- $\quad$ the actual banking system would be providing means to support Mozambican SMEs;

- $\quad$ Mozambican SMEs are those that are majority-owned by Mozambicans;

- $\quad$ the activities would be defined beforehand, privileging those that produce material goods and services and to the detriment of trade in imported goods; and

- $\quad$ housing loans for young people would also be eligible.

The interest rates would obviously be lower than market rates. For example, 50 per cent of the prime rate, bearing in mind that these resources would otherwise be remunerated as Mandatory Reserves.

\subsection{Support measures for family farmers}

Contrary to the case of SMEs, there are few direct initiatives providing support to rural families, i.e. rural family farmers.

For many years, and mainly after the Peace Accords in 1992, many investments were made to rebuild infrastructures and restore the trade relations destroyed during the War of Destabilization. As a result, major progress was achieved in terms of reducing poverty.

However, this model for reducing poverty through providing public goods and services has been exhausted. This is because the central issue, i.e. increasing the productivity of farming families, was neglected or at least not dealt with so intensively. Therefore, when we refer to support initiatives, we mean support programmes to increase the productivity of families. Unfortunately, neither the government nor the community took any hand in developing significant rural development programmes. Only very recently has the government, with the support of the World Bank and other donors, launched the Sustenta Programme, with the aim of supporting country families and SMEs in the agricultural sector. The programme already referred to, 'One District, One Bank', was launched in this context.

There are several reasons for this apparent lack of interest from the donor community and multilateral financial institutions, particularly the following:

- lack of success with similar experiences in several countries;

- slow progress and, particularly, little visibility, unlike roads, hospitals, schools and water supply; 
- complex programmes that require the involvement of lots of state organizations at all levels, which is not always possible or accepted. For example, any programme of this nature would require changing the functions of the district and local administrator and the main aim would be to improve the living conditions of the people through increasing productivity, to the detriment, if necessary, of the representation functions of the central power.

In order not to make the mistake of engaging in large rural development programmes like large dams, roads, silos, etc.- that require high investments with low profitability and long recovery periods - the immediate aim is to take advantage of the existing infrastructures, renovating them if necessary or boosting their capacity, instead of building from scratch. In other words, the aim of a programme of this type is to empower the people, i.e. the rural families, increasing their productive capacity and ensuring financial support for:

- increasing their activity, extending the cultivated area and hiring more seasonal labourers and/or leasing mechanized services;

- adopting higher-yield crops;

- planting fruit trees, using more productive varieties (e.g. replanting cashew trees);

- using improved seeds and fertilizer;

- building sheds especially designed for storing the products;

- acquiring more appropriate farming tools.

Given how backward subsistence farming is, a simple programme of this kind could bring considerable returns very quickly and, at the same time, be a catalyst for other institutional changes necessary to ensure the success of a simple programme but one that requires major changes at several levels, such as: better seeds, availability of seeds, reinforcement of marketing and food conservation, reinforcement of the extension service, reinforcement of rural shops for buying agricultural production and the sale of the goods needed by rural families, and-more difficult-a change in the attitudes and focus of public administration.

This programme which essentially consists of granting credit to rural families that meet a set of requirements will be strategic, as its implementation will force, even at the expense of conflicts and frustration, the alteration of other institutions and the emergence of other organizations. In the centre of these organizations will be the agriculture bank, as described above, which will use the existing digital platforms-M-Pesa, Mkesh and commercial banks for its operation. As it is not a bank the customer actually goes to, these will be as simple as possible, with no need for safes at their branches or delegations, as they will not be dealing with physical money but rather with digital money. The use of these platforms will allow the operators to be called banking agents that can make a bridge with the farmers. If possible, these banking agents could receive extensionist training.

A programme of this type will cover only a part of the 3.8 million rural families in the first stage, but still a high number in absolute terms, as it is believed that almost 800,000 families meet the requirements mentioned above - a farmer that hires a labourer, etc. The initial number will be even lower, as it should begin in regions or areas with more agricultural potential or with better infrastructures, such as: the Limpopo and Sabié irrigation complexes, in high altitude areas such as Angónia, Ribaué, Niassa, Malema, etc.

Until it has been legally established that transactions can be made using the right to use and benefit from the land (DUAT), it will not be possible to use this as a guarantee, nor will it be possible to consider the possibility of attachment of production, as this is very complex and difficult 
administratively. Under these circumstances, the only way of leveraging a family in debt is the prohibition of further loans during the period of breach. In such circumstances, this programme should be looked at as a public investment and not as a commercial operation. Therefore, the loans must not be commercial in nature and thus it will not be possible, or desirable, for commercial banks to be involved.

Finally, it is important to note that a credit programme as vast as the one proposed is only possible thanks to digital platforms, because if commercial banks were used, the administrative costs would be prohibitive and the interest rates extremely high.

\section{$6 \quad$ Final considerations}

Although the financial inclusion effort has achieved positive results and, as a result, access to banking services by Mozambicans has increased considerably, the economic and social impact has been limited if the criteria are an increase in productivity and a reduction in poverty. This is because during the period when greater efforts were made to provide access to banking services, poverty increased both in absolute and in relative terms.

Non-inclusion of credit in the financial inclusion efforts partially explains this lack of impact. However, the expansion of credit, while crucial and having the ability to create new dynamics, both in towns and cities and in the countryside, requires appropriate institutions both at macro level and specifically in the financial system.

Institutions at macro level have been deteriorating and the immense political capital existing in national independence at the time has been exhausted. The rebuilding of these macro-institutions is a complex, and very complicated, problem. The many reforms needed can only have an expectation of success under the framework of more inclusive and equitable development.

The proposal for setting up new institutions in the financial sector, whose success requires institutional reform in other sectors, may have a catalysing effect, i.e. it may help the process of rebuilding some macro-institutions. This catalysing effect could come in part from improving the living conditions of the population, who will then recognize that the state has legitimacy once more.

The proposals presented are few in number but have profound implications, and, with regard to financial support for family farmers, should be understood as a public investment and not a commercial enterprise. A public investment whose political and economic returns will be enormous if the policies are correctly implemented, under a comprehensive framework of reforms.

\section{References}

BM - Banco de Moçambique (2016). Estratégia Nacional de Inclusão Financeira: 2016-2022. Maputo: BM. Available at: http:/ /www.bancomoc.mz/fm_pgTab1.aspx?id=300 (accessed on 22 July 2020).

BM - Banco de Moçambique (2019). Relatório de Inclusão Financeira 2018. Maputo: BM. Available at http:/ /www.bancomoc.mz/fm_pgTab1.aspx?id=302 (accessed on 29 July 2020).

BM - Banco de Moçambique (2020). Banca electrónica: Estatísticas sobre ATM, POS e cartões 2019. Maputo: BM. Available at http://www.bancomoc.mz/fm_pgTab1.aspx?id=27 (accessed on 23 July 2020). 
COWI (2015). Inquérito ao Consumo FinScope Mocambique 2014. Maputo: FinMark Trust. Available at http://www.finmark.org.za/wp-content/uploads/2015/09/BROCH_FS_Moz_

Portuguese_2014-1 002603. (accessed on 27 July 2020).

Oxford Policy Management (2019). Economic Development Institutions: Institutional Diagnostic Tool. Available at https://edi.opml.co.uk/wpcms/wp-content/uploads/2019/06/ Mozambique-InstitutionalDiagnostic-June2019.pdf.

Fernandes, C. R. (2018). 'A Inclusão Financeira em Moçambique: Situação Actual e Oportunidades'. Conferência sobre serviços financeiros digitais, 28 de Maio de 2018. Maputo: FSD Moçambique. Available at http://fsdmoc.com/wp-content/uploads/ 2018/05/2018-PPT-3.-A-Inclus\%C3\%A3o-Financeira-em-Mo\%C3\%A7ambique-

Situa\%C3\%A7\%C3\%A3o-Actual-e-Oportunidades-Carla-Rosario-Fernandes-May-28th.pdf (accessed on 23 July 2020).

FSDMoç (2017). Promovendo a Inclusão Financeira de Agregados Familiares de Pequenos Produtores em Moçambique. Maputo: FSDMoç. Available at http://fsdmoc.com/wpcontent/uploads/2017/11/Promovendo-a-Inclus\%C3\%A3o-Financeira-de-Agregados-

Familiares-de-Pequenos-Produtores-em-Mo\%C3\%A7ambique.pdf (accessed on 29 July 2020).

INE - Instituto Nacional de Estatística (2019a). Anuário Estatístico, 2018. Maputo: INE.

INE - Instituto Nacional de Estatística (2019b). Censo 2017: IV recenseamento geral da população de habitação, resultados definitivos. Maputo: INE. Available at http://www.ine.gov.mz/iv-rgph2017/mocambique/apresentacao-resultados-do-censo-2017-1/view (accessed on 3 May 2019).

KPMG and AMB - Associação Moçambicana de Bancos (2019). 'Pesquisa sobre o Sector Bancário'. Maputo: KPMG; AMB. Available at http://www.amb.co.mz/index.php/publicacao/ pesquisa-do-sector-bancario/43-pesquisa-do-sector-bancario-novembro-2019/file (accessed on 29 July 2020).

MITADER (2016). Programa Nacional de Desenvolvimento Sustentável. Maputo: MITADER. Available at https://www.mitader.gov.mz/wp-content/uploads/2016/12/MITADER_ DESENVOLVIMENTO_SUSTENTAVEL_1.pdf (accessed on 25 July 2020).

Vletter, F. de, Lauchande, C., and Infante, E. (2015). FinScope Consumer Survey Mozambique 2014. Maputo: FinMark Trust. Available at http://www.finmark.org.za/wpcontent//2015/09/Rep_FS_MOZ_2014 -1.(accessed on 26 July 2020). 